\title{
Penerapan Data Mining untuk Mengcluster Data Penduduk Miskin Menggunakan Algoritma K- Means di Dusun Bagik Endep Sukamulia Timur
}

\author{
Suhartini ${ }^{1}$, Ria Yuliani ${ }^{2}$ \\ 1Program Studi Teknik Informatika, Universitas Hamzanwadi \\ 2Program Studi Sistem Informasi Universitas Hamzanwadi \\ Suhartini311279@gmail.com
}

\begin{abstract}
Abstrak
Terjadinya kemiskinan pada masyarakat disebabkan oleh suatu kondisi ketidakmampuan kepala keluarga secara ekonomi untuk memenuhi kebutuhan primer/ pokok keluarganya yaitu kebutuhan sandang, pangan, papan serta pendidikan. Masyarakat miskin itu sendiri hampir terdapat pada setiap Negara, Kota maupun Daerah contohnya disalah satu Dusun Bagik Endep Desa Sukamulia Timur.[1] Berdasarkan kondisi tersebut perlu dilakukannya pengklasteran untuk membantu Pemerintah desa dalam pengelompokan keluarga miskin, sehingga bantuan dapat disalurkan dengan tepat. Dengan mengamati persoalan di atas maka diperlukan Data Mining untuk mengelompokkan peneriman bantuan dengan menggunakan metode K-Means dalam pengklasteran penduduk miskin. Dimana metode Algoritme K-Means Clustering ini bertujuan untuk mengelompokkan data penduduk di wilayah Sukamulia Timur yang memang dikatakan tergolong penduduk miskin. Data yang digunakan adalah data Penduduk Sukamulia Timur pada tahun 2019 yang berjumlah 200 data dengan 9 atribut yaitu nama penduduk, pekerjaan, penghasilan/bulan, jumlah anak yang sekolah SD, jumlah anak yang sekolah SMP, jumlah anak yang sekolah SMA, jumlah anak yang kuliah, jumlah anak yang tidak sekolah serta jumlah anggota keluarga. Berdasarkan hasil pengujian yang dilakukan dengan menerapkan algoritma K-Means didapatkan hasil dengan Cluster 1 berjumlah 18 penduduk dengan kriteria Penduduk ekonomi tinggi, Cluster 2 berjumlah 72 Penduduk dengan kriteria Penduduk ekonomi sedang, dan Cluster 3 berjumlah 110 penduduk dengan kriteria Penduduk ekonomi rendah[2]. Metode K-Means ini diharapkan mampu membantu pemerintah Desa Sukamulia Timur dalam pengambilan keputusan dan menemukan informasi yang dibutuhkan untuk memecahkan masalah dalam mendata penduduk miskin dengan tepat.
\end{abstract}

Kata Kunci : Data Mining, K-Means Clustering, Kemiskinan

\begin{abstract}
The occurrence of poverty in the community is caused by a condition of the economic inability of the head of the family to meet the primary / basic needs of his family, namely the need for clothing, food, shelter and education. The poor community itself can be found in almost every country, city and region, for example in one of the Bagik Endep hamlets of East Sukamulia Village. Based on these conditions, it is necessary to carry out clustering to assist the village government in grouping poor families, so that assistance can be distributed appropriately. By observing the above problems, Data Mining is needed to classify aid recipients using the K-Means method in clustering the poor. Where the K-Means Clustering Algorithm method aims to classify population data in the East Sukamulia region who are said to be classified as poor. The data used is data on the population of East Sukamulia in 2019, amounting to 200 data with 9 attributes, namely the name of the population, occupation, income / month, the number of children attending elementary school, the number of children attending junior high school, the number of children attending high school, the number of children attending college , the number of children who are not in school and the number of family members. Based on the results of tests carried out by applying the K-Means algorithm, the results obtained are Cluster 1 totaling 18 residents with the criteria of high economic population, Cluster 2 totaling 72 residents with moderate economic population criteria, and Cluster 3 totaling 110 residents with low economic population criteria. The K-Means method is expected to be able to assist
\end{abstract}


DOI : 10.29408/jit.v4i1.2986 Link : https://dx.doi.org/10.29408/jit.v4i1.2986

the government of Sukamulia Timur Village in making decisions and finding the information needed to solve problems in recording the poor population accurately.

Keywords: Data Mining, K-Means Clustering, Proverty

\section{Pendahuluan}

Bagi Pemerintah Indonesia masalah kemiskinan adalah salah satu masalah yang sudah lama dan belum bisa diselesaikan. Masalah kemiskinan ini terjadi hampir disetiap wilayah salah satunya wilayah Desa Sukamulia Timur. Kemiskinan dapat disebabkan oleh kelangkaan kebutuhan dasar terhadap pendidikan dan pekerjaan. Pemerintah sendiri telah melakukan beberapa upaya dalam mengatasi kemiskinan diantaranya melalui program bantuan sosial seperti tunjangan, Jaminan Kesehatan Masyarakat, Beras Miskin (Raskin), Program Keluarga Harapan (PKH), Bantuan Biaya Peningkatan Prestasi Akademik (BBP-PPA), Bantuan biaya pendidikan yang hanya ditujukan untuk calon Mahasiswa tidak mampu/miskin (BIDIKMISI) dan program-program lainnya, tetapi pada kenyataannya masalah kemiskinan belum dapat ditanggulangi.[3]

Tingkat kemiskinan ini juga dipengaruhi oleh salah satunya yaitu lapangan kerja yang kurang memadai atau pekerjaan yang dimiliki mempunyai penghasilan yang tidak sesuai dengan tanggungan hidup seperti tanggungan dalam keluarga, anak dan lain sebagainya. Selain lapangan pekerjaan yang kurang memadai, ternyata salah satu penyebab masalah kemiskanan belum bisa diselesaikan adalah dari hasil survey yang dilakukan bantuan yang diberikan pemerintah kepada penduduk tidak sesuai dengan apa yang mereka butuhkan. Salah satu kesulitan yang terkadang dihadapi Pemerintah dalam proses penanganan kemiskinan adalah proses pembagian bantuan sosial yang tidak merata dan tidak tepat sasaran. Ini disebabkan karena validasi data sering diabaikan sehingga sering menimbulkan data yang tidak akurat. Dengan adanya permasalahan tersebut, penulis akan mencoba menggunakan metode yaitu dengan pendekatan metode data mining. Dengan pendekatan data mining, penulis juga menerapkan metode Algoritma K-Means Clustering. Dimana metode Algoritme K-Means Clustering ini bertujuan mengelompokkan data penduduk di wilayah Sukamulia Timur yang memang dikatakan tergolong penduduk miskin. Data yang digunakan adalah data Penduduk Sukamulia Timur pada tahun 2019. Dengan metode cluster ini, dapat membantu Kantor Desa Sukamulia Timur dalam pengambilan keputusan dan menemukan informasi yang dibutuhkan untuk memecahkan masalah dalam mendata penduduk miskin dengan tepat. maka peneiti tertarik untuk melakukan pengkajian 
DOI : 10.29408/jit.v4i1.2986 Link : https://dx.doi.org/10.29408/jit.v4i1.2986

tentang data penduduk miskin dengan judul "Penerapan Data Mining untuk Clustering Data Penduduk Miskin Menggunakan Algoritma KMeans di Dusun Bagik Endep Sukamulia Timur".[4]

\section{Tinjauan Pustaka}

\subsection{Penelitian Terkait}

- Penelitian yang dilakukan oleh Riyani Wulan Sari, Anjar Wanto, Agus Perdana Windarto dalam jurnal yang berjudul "Implementasi Rapidminer Dengan Metode K-Means (Study Kasus: Imunisasi Campak Pada Balita Berdasarkan Provinsi)",Data yang digunakan dalam penelitian ini yaitu data dari tahun 20042017 yang terdiri dari 34 provinsi .[5]

- Selanjutnya penelitian dilakukan oleh Devi Sartika, Juju Jumadi,dalam jurnal yang berjudul"Clustering Penilaian Kinerja Dosen Menggunakan Algoritma K-Means (Studi Kasus: Universitas Dehasen Bengkulu), Permasalahan yang dihadapi dalam penelitian ini adalah kesulitannya pembuat kebijakan yang dalam hal ini adalah pihak akademik kampus Universitas Dehasen Bengkulu untuk mengelompokkan dosen yang melakukan kegiatan mengajar dengan kualitas sangat baik, baik, cukup baik dan kurang baik sehingga dibutuhkan suatu teknik klasterisasi data.[6]
Penelitian berikutnya dilakukan oleh Windania Purba, Willy Siawin, Hardih, dalam jurnal yang berjudul "Implementasi Data Mining Untuk Pengelompokkan Dan Prediksi Karyawan Yang Berpotensi Phk Dengan Algoritma K-Means Clustering" .[3]

- Penelitian yang dilakukan oleh Asroni, Ronald Adrian,dalam jurnal yang berjudul "Penerapan Metode K-Means Untuk Clustering Mahasiswa Berdasarkan Nilai Akademik Dengan Weka Interface Studi Kasus Pada Jurusan Teknik Informatika UMM Magelang" Penelitian ini menguji data yang telah ada di data warehouse Universitas Muhammadiyah Magelang untuk memudahkan untuk mencari 5 orang mahasiswa pada jurusan Teknik Informatika dalam melakukan penyeleksian untuk mengikuti lomba.[7]

Penelilitian yang di lakukan oleh Donni prima dalam " judul Pengelompokan Kecamatan-Kecamatan Di Jakarta Barat Berdasarkan Jumlah Penyandang Masalah Kesejahteraan Sosial Tahun 2013 Dengan Menggunakan Metode Algoritma K-Means" Peneliti melakukan penelitian dengan melihat gambaran secara umum masalah kesejahteraan di Jakarta Barat Masalah kesejahteraan yang tertinggi di kota Jakarta Barat adalah fakir miskin, lansia terlantar dan anak terlantar. Kecamatan yang 
DOI : 10.29408/jit.v4i1.2986 Link : https://dx.doi.org/10.29408/jit.v4i1.2986

memiliki masalah kesejahteraan sosial terkompleks selaras dengan jumlah penyandang terbanyak adalah kecamatan Kembangan. [8]

\subsection{Landasan Teori}

\section{Penduduk Miskin}

Kemiskinan adalah apabila pendapatan suatu komunitas berada dibawah garis kemiskinan tertentu.Kemiskinan juga berarti kekurangan kebutuhan social, termasuk keterkucilan social, ketergantungan dan ketidakmampuan berpartisipasi dalam kehidupan masyarakat yang layak.Secara arti sempitnya kemiskinan dipahami sebagai keadaan kekurangan uang dan barang untuk menjamin kelangsungan hidup yang seharusnya. Menurut Hasya Yanto: "kemiskinan adalah keadaan dimana seseorang yang tidak bisa memenuhi kebutuhan hidupnya". Kemiskinan adalah keadaan dimana terjadi ketidakmampuan untuk memenuhi kebutuhan dasar seperti makanan, pakaian, tempat berlindung dan pendidikan.Kemiskinan secara konseptual dibedakan menurut kemiskinan relative dan kemiskinan absolute.Dimana perbedaannya terletak pada standar penilaiannya. Standar penilaian kemiskinan relative merupakan standar kehidupan yang ditentukan dan ditetapkan secara subyektif oleh masyarakat setempat dan bersifat local serta mereka yang berada dbawah standar penilaian tersebut dikatagorikan sebagai miskin secara relatif.Sedangkan standar penilaian secara absolute merupakan standar kehidupan minuman yang dibutuhkan untuk memnuhi kebutuhan dasar yang diperlukan, baik makann maupun non makanan.Standar kehidupan minuman untuk memenuhi kebutuhan dasar ini disebut sebagai garis kemiskinan.Jadi dapat disimpulkan bahwa kemiskinan dimana seseorang tidak dapat memenuhi kebutuhan hidupnya seperti kebutuhan makanan, pakaian, tempat tinggal, dan pendidikan.[9]

Menyambung hal diatas, kemiskinan di Indonesia yang banyak dibicarakan ini tentunya mempunyai dasar. Oleh karena itu, kemiskinan yang dimaksud ini telah di dasari UndangUndang RI nomor 13 tahun 2011 tentang penanganan Penduduk Miskin. Pasal 1(1) UU tersebut menyebutkan bahwa "Penduduk Miskin adalah orang yang sama sekali tidak mempunyai mata pencaharian dan/atau mempunyai sumber penghasilan tetapi tidak mempunyai kemampuan untuk memenuhi kebutuhan dasar yang layak bagi kehidupan dirinya dan keluarganya.

\section{Data Mining}

Data mining merupakan salah satu solusi untuk menjelaskan proses penambangan informasi dalam suatu basis data yang berskala besar.[10] Saat suatu organisasi baik itu 
DOI : 10.29408/jit.v4i1.2986 Link : https://dx.doi.org/10.29408/jit.v4i1.2986

perusahaan maupun suatu institusi yang mempunyai data yang kompleks, tidak menutup kemungkinan banyak sekali informasi yang dapat diperoleh, serta bagaimana solusi data mining bisa diterapkan dengan berbagai teknik diantaranya yaitu classification, association dan clustering.[11]

a. Deskripsi

Para peneliti biasanya mencoba menemukan cara untuk mendeskripsi pola dan trend yang tersembunyi dalam data.

b. Estimasi

Estimasi mirip dengan klasifikasi, kecuali variabel tujuan yang lebih kearah numerik dari pada kategori.

c. Prediksi

Prediksi memiliki kemiripan dengan estimasi dan klasifikasi. Hanya saja, prediksi hasilnya menunjukkan sesuatu yang belum terjadi (mungkin terjadi dimasa depan).

d. Klasifikasi

Dalam klasifikasi variabel, tujuan bersifat kategorik. Misalnya, kita akan mengklasifikasikan pendapatan dalam tiga kelas, yaitu pendapatan tinggi, pendapatan sedang, dan pendapatan rendah.

e. Clustering

Clustering lebih ke arah pengelompokan record, pengamatan, atau kasus dalam kelas yang memiliki kemiripan.

\section{f. Asosiasi}

Mengidentifikasi hubungan antara berbagai peristiwa yang terjadi pada satu waktu.

\section{Algoritma K-Means}

K-Means merupakan sebuah algoritma clustering pada data mining untuk dapat menghasilkan kelompok dari data yang jumlahnya banyak dengan metode partisi yang berbasis titik dengan waktu komputasi yang cepat dan efisien. Selain itu definisi K-Means merupakan metode clustering berbasis jarak yang membagi data ke dalam sejumlah cluster dan algoritma ini hanya bekerja pada atribut numerik. Dapat disimpulkan bahwa algoritma KMeans akan membuat data-data yang ingin dilakukan cluster nantinya akan menuju beberapa pusat/titik dimana titik tersebutlah yang digunakan sebagai acuan dalam pengelompokan dan data-data yang dilakukan klasterisasi harus numerik. Pada dasarnya Algoritma K-Means hanya mengambil sebagian dari banyaknya dari komponen yang didapatkan untuk kemudian dijadikan pusat cluster awal, pada penentuan pusat cluster ini dipilih secara acak dari populasi data.

\section{K-Means Clustering}

Data Clustering merupakan salah satu metode Data Mining yang bersifat tanpa arahan (unsupervised). K-Means merupakan salah satu metode data clustering non hirarki yang 
DOI : 10.29408/jit.v4i1.2986 Link : https://dx.doi.org/10.29408/jit.v4i1.2986

berusaha mempartisi data yang ada ke dalam bentuk satu atau lebih cluster/ kelompok. Metode ini mempartisi data ke dalam cluster/ kelompok sehingga data yang memiliki karakteristik yang sama dikelompokkan ke dalam satu cluster yang sama dan data yang mempunyai karakteristik yang berbeda dikelompokkan ke dalam kelompok yang lain.[8] Manfaat Clustering adalah sebagai Identifikasi Object (Recognition) misalnya dalam bidang Image Processing, Computer Vision atau robot vision. Selain itu adalah sebagai Sistem Pendukung Keputusan dan Data Mining seperti Segmentasi pasar, pemetaan wilayah, Manajemen marketing dan lain-lain.

Karakteristik K-means :

- K-means sangat cepat dalam proses clustering.

- K-means sangat sensitive pada pembangkitan centroid awal secara random.

- Memungkinkan suatu cluster tidak mempunyai anggota.

- Hasil clustering dengan K-means bersifat unik (selalu berubah-ubah,

- Terkadang baik, terkadang jelek).

\subsection{Tahapan Penelitian}

Adapun tahapan dari penelitian ini meliputi beberapa tahapan diantaranya:
1. Tahap pengumpulan informasi mengenai data-data penduduk Dusun Bagik endep Sukamulia Timur.

2. Tahap Analisis

Pada tahap analisis ini sistem meliputi: pengumpulan fakta sebagai dasar untuk mempelajari suatu sistem yang ada seperti : kondisi prekonomian penduduk serta masalah yang dihadapi.

3. Tahap Pemahaman Data

Data penduduk yang penulis gunakan ini diambil dari data Penduduk Dusun Bagik Endep Sukamulia Timur. Didalam data ini terdapat 200 penduduk, dan dalam data ini ada beberapa data penduduk yang dijadikan sebagai atribut yaitu : Pekerjaan, Penghasilan, jumlah anak yang masih dalam jenjang pendidikan dan jumlah anggota keluarga.

\section{Tahap Persiapan Data}

Pada tahap ini data sebanyak 200 dan terdiri dari 9 atribut yang akan dilakukan beberapa penyelesaian untuk menghasilkan data yang dibutuhkan. Tahapannya yaitu :

a. Pembersihan Data : untuk membersihkan nilai yang kosong

b. Pengurangan Data : jumlah atribut data yan digunakan tidak semua yang terdapat dalam database, oleh karena itu atribut yang tidak diperlukan atau tidak digunakan akan dihapus[12] 
DOI : 10.29408/jit.v4i1.2986 Link : https://dx.doi.org/10.29408/jit.v4i1.2986

\section{Metode Penelitian}

Untuk mendapatkan data dan informasi yang dibutuhkan ada beberapa cara yang penulis lakukakan untuk mendapatkan data dan informasi yang benar dan jelas yaitu sebagai berikut:

a. Observasi :Dalam metode ini peneliti mengumpulkan data dengan melakukan observasi / pengamatan ke Kantor Desa Sukamulia Timur..

b. Wawancara : Wawancara atau tanya jawab dilakukan dengan staf Kantor Desa Sukamulia Timur untuk mengetahui gambaran tentang kondisi prekonomian Penduduk.

c. Studi Pustaka : Metode ini dilakukan untuk menunjang metode wawancara dan observasi yang telah dilakukan. Dalam pengumpulan informasi yang dibutuhkan perlu mencari refrensi-refrensi yang berhubungan dengan penelitian refrensi yang dapat diperoleh dari buku maupun internet.

\section{Hasil dan Pembahasan}

\subsection{Tahap Clustering dengan Metode K-Means}

Tahapan melakukan clustering atau pengelompokan dengan metode K-Means adalah sebagai berikut [13] a. Tentukan jumlah cluster $\mathrm{k}$.

b. Pilih pusat cluster secara acak. Pemilihan pusat cluster ini bisa dilakukan dengan berbagai cara, yang paling sering dilakukan adalah dengan cara random (acak). Namun pada penelitian ini pusat cluster ditentukan dari yang tertinggi ke terendah.

c. Jarak anatara data dan pusat cluster dihitung menggunakan Euclidean Distance. Untuk menghitung semua jarak data ke setiap titik pusat cluster dapat menggunakan teori jarak Euclidean yang dirumuskan sebagai berikut :

$$
d\left(x_{j}, c_{j}\right)=\sqrt{\sum_{j=1}^{n}\left(x_{j}-c_{j}\right)^{2}}
$$

Dimana :

d $\quad=$ jarak

$x_{j} \quad=$ Data ke $-j$

$c_{j} \quad=$ centroid $k e-j$

d. Data ditempatkan dalam cluster yang terdekat, dihitung dari tengah cluster.

e. Pusat cluster baru akan ditentukan bila semua data telah ditetapkan dalam cluster terdekat.

f. Proses penentuan pusat cluster dan penempatan data dalam cluster dilulangi sampai nilai centroid tidak berubah lagi.

Adapun alur proses data yang akan diterapkan menggunakan algoritma K-Means untuk 
DOI : 10.29408/jit.v4i1.2986 Link : https://dx.doi.org/10.29408/jit.v4i1.2986

pendataan Penduduk Miskin berdasarkan data penduduk 2019 dapat dilihat pada diagram alur proses di bawah :

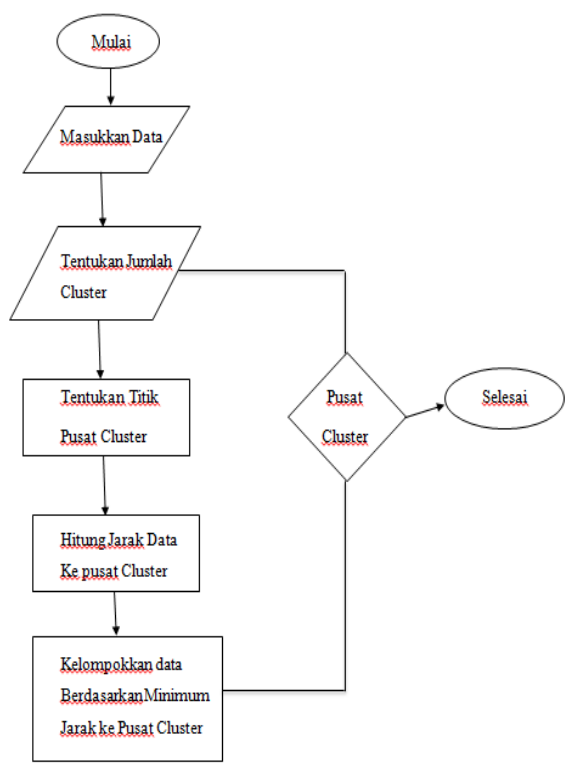

Gambar 1 Diagram alur proses

\subsection{Cluster Model (Clustering)}

Gambar 1 merupakan sheet untuk menampilkan database yang telah diolah secara keseluruhan lengkap dengan clusternya. Hasil dari data 200 dimana C0 memiliki 18 items, C1 memiliki 72 items, C2 memiliki 110 items.[14]

\section{Cluster Model \\ Cluster $0: 18$ items Cluster 1: 72 items Cluster 2: 110 items Total number of items: 200}

\section{Gambar 2 Cluster Model}

\subsection{Pengelompokkan Data/ Iterasi}

1. Iterasi Pertama
Pada iterasi pertama nilai centroid awal pada penelitian ini dilakukan pemilihan dari tertinggiTerendah dengan jumlah centroid awal dilakukan sebanyak tiga centroid awal, yaitu:

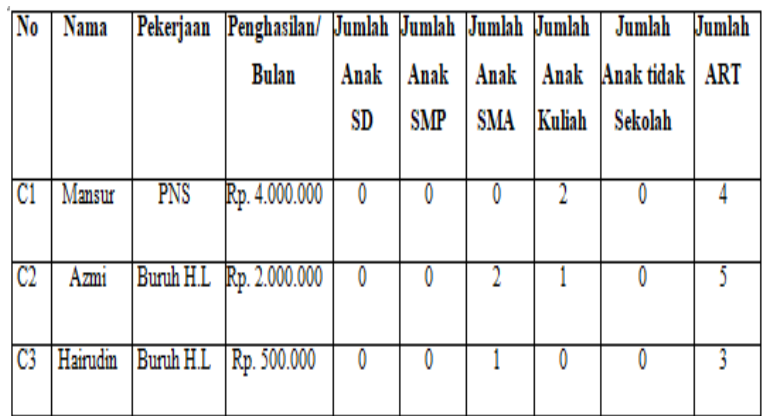

Gambar 3 Centroid Awal/Pertama

Dibawah ini merupakan hasil iterasi/percobaan yang telah dilakukan pada Microsoft Exel :

\begin{tabular}{|l|r|r|r|r|l|l|}
\hline 3000000 & 1000000 & 500000 & 500000 & & & 1 \\
\hline 2500000 & 500000 & 1000000 & 500000 & & 1 & \\
\hline 2500000 & 500000 & 1000000 & 500000 & & 1 & \\
\hline 3000000 & 1000000 & 500000 & 500000 & & & 1 \\
\hline 2000000 & 3.741657387 & 1500000 & 3.741657387 & & 1 & \\
\hline 2500000 & 500000 & 1000000 & 500000 & & 1 & \\
\hline 3000000 & 1000000 & 500000 & 500000 & & & 1 \\
\hline 2000000 & 2.449489743 & 1500000 & 2.449489743 & & 1 & \\
\hline 2500000 & 500000 & 1000000 & 500000 & & 1 & \\
\hline 2000000 & 2.828427125 & 1500000 & 2.828427125 & & 1 & \\
\hline 2500000 & 500000 & 1000000 & 500000 & & 1 & \\
\hline 3000000 & 1000000 & 500000 & 500000 & & & 1 \\
\hline 3000000 & 1000000 & 500000 & 500000 & & & 1 \\
\hline 3000000 & 1000000 & 500000 & 500000 & & & 1 \\
\hline 2000000 & 3.16227766 & 1500000 & 3.16227766 & & 1 & \\
\hline 3500000 & 1500000 & 1.732050808 & 1.732050808 & & & 1 \\
\hline 3000000 & 1000000 & 500000 & 500000 & & & 1 \\
\hline 2000000 & 3.16227766 & 1500000 & 3.16227766 & & 1 & \\
\hline 1000000 & 1000000 & 2500000 & 1000000 & 1 & & \\
\hline 3000000 & 1000000 & 500000 & 500000 & & & 1 \\
\hline 3300000 & 1300000 & 200000 & 200000 & & & 1 \\
\hline 3500000 & 1500000 & 1.732050808 & 1.732050808 & & & 1 \\
\hline 3000000 & 1000000 & 500000 & 500000 & & & 1 \\
\hline & & & & & 1 \\
\hline
\end{tabular}

Gambar 4 Iterasi Pertama

Berdasarkan proses iterasi 1 terlihat pada titik pusat cluster yang diproses sama, untuk melakukan perhitungan kembali untuk membuktikan apakah hasil iterasi 1 akan tetap sama sampai iterasi seterusnya.

2. Iterasi ke dua 
DOI : 10.29408/jit.v4i1.2986 Link : https://dx.doi.org/10.29408/jit.v4i1.2986

Iterasi ini dilakukan untuk membuktikan apakah hasil yang diperoleh pada iterasi pertama akan tetap sama atau akan berbeda.

\begin{tabular}{|c|c|c|c|c|c|c|c|}
\hline & $\begin{array}{c}\text { Penghasilan } \\
\text { / } \\
\text { Bulan }\end{array}$ & $\begin{array}{c}\text { Jumlah } \\
\text { Anak } \\
\text { SD }\end{array}$ & $\begin{array}{c}\text { Jumlah } \\
\text { Anak } \\
\text { SIP }\end{array}$ & $\begin{array}{c}\text { Jumlah } \\
\text { Anak } \\
\text { S.MA }\end{array}$ & $\begin{array}{c}\text { Jumlah } \\
\text { Anak } \\
\text { Kullah }\end{array}$ & \begin{tabular}{|c|} 
Jumlah \\
Anak tidak \\
Sekolah
\end{tabular} & $\begin{array}{l}\text { Jumlah } \\
\text { ART }\end{array}$ \\
\hline & \begin{tabular}{|l|l|l|}
39888888899 \\
\end{tabular} & 0.722222222 & 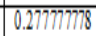 & 0.2777778 & $\mid 0.1666666667$ & 3.88888 & 3.44444 \\
\hline & 1770833333 & 20834.0694 & 20833.63889 & \begin{tabular}{|l|}
3.04166607 \\
\end{tabular} & 0.09722222 & 0.513888889 & 3.91666660 \\
\hline & 84045.4 .5452 & & 0.272727273 & 0.3272727 & 0.018181818 & 0.418181818 & 3.5545454 \\
\hline
\end{tabular}

Gambar 5 Centroid Kedua

Berikut ini merupakan hal perbandingan jarak antara data dengan centroid setiap cluster yang ada. Perhitungan dilakukan terus sampai data ke-200 terhadap pusat cluster. Setelah dilakukan proses perhitungan maka akan didapatkan hasil data sebagai berikut :

\begin{tabular}{|l|l|l|l|l|l|l|}
\hline 2988888.889 & 771396.219 & 159545.4545 & 159545.4545 & & & 1 \\
\hline 1988888.889 & 231052.5772 & 1159545.455 & 231052.5772 & & 1 & \\
\hline 2488888.889 & 272431.2636 & 659545.4545 & 272431.2636 & & 1 & \\
\hline 2988888.889 & 771396.219 & 159545.4546 & 159545.4546 & & & 1 \\
\hline 1988888.889 & 231052.7575 & 1159545.455 & 231052.7575 & & 1 & \\
\hline 2488888.889 & 272431.1872 & 659545.4545 & 272431.1872 & & 1 & \\
\hline 1988888.889 & 231052.8477 & 1159545.455 & 231052.8477 & & 1 & \\
\hline 2488888.889 & 272431.1107 & 659545.4545 & 272431.1107 & & 1 & \\
\hline 2988888.889 & 771396.192 & 159545.4545 & 159545.4545 & & & 1 \\
\hline 2988888.889 & 771396.192 & 159545.4546 & 159545.4546 & & & 1 \\
\hline 2988888.889 & 771396.138 & 159545.4545 & 159545.4546 & & & 1 \\
\hline 1988888.889 & 231052.9378 & 1159545.455 & 231052.9378 & & 1 & \\
\hline 3488888.889 & 1271174.818 & 340454.5455 & 340454.5455 & & & 1 \\
\hline 2988888.889 & 771396.219 & 159545.4545 & 159545.4545 & & & 1 \\
\hline 1988888.889 & 231052.9378 & 1159545.455 & 231052.9378 & & 1 & \\
\hline 988888.8889 & 1229519.741 & 2159545.455 & 988888.8889 & 1 & & \\
\hline 2988888.889 & 771396.219 & 159545.4546 & 159545.4546 & & & 1 \\
\hline 3288888.889 & 1071238.575 & 140454.5455 & 140454.5455 & & & 1 \\
\hline 3488888.889 & 1271174.818 & 340454.5455 & 340454.5455 & & & 1 \\
\hline 2988888.889 & 771396.219 & 159545.4545 & 159545.4546 & & & 1 \\
\hline 2488888.889 & 272431.1872 & 659545.4545 & 272431.1872 & & 1 & \\
\hline & & & & 18 & 72 & 110 \\
\hline
\end{tabular}

Gambar 6 Iterasi Kedua

Dapat terlihat pada iterasi ke 1 dan iterasi ke 2 tidak lagi mengalami perubahan pada titik cluster, sehingga dapat disimpulkan bahwa iterasi dapat dihentikan pada iterasi ke 2 dengan hasil :

- Cluster pertama $=18$ Penduduk

- Cluster kedua = 72 Penduduk

- Cluster Ketiga $\quad=110$ Penduduk

\subsection{Hasil Pengelompokkan Masing-Masing Cluster}

Berdasarkan hasil pengelompokan dari seluruh data menggunakan metode k-means clustering, didapatkan hasil akhir pengelompokan hingga iterasi ke-2, dimana titik pusat tidak lagi berubah dan tidak ada data yang berpindah antar cluster. Hasil cluster yang terbentuk dari setiap data tersebut dapat dilihat pada table 1 dibawah ini:

Table 1 Pengelompokkan Data Penduduk

\begin{tabular}{|c|c|}
\hline Cluster & Data Penduduk \\
\hline Cluster 1 & $\begin{array}{l}17,45,47,54,64,76,81,91, \\
110,122,129,135,147,158, \\
166,172,191,198 .\end{array}$ \\
\hline Cluster 2 & $\begin{array}{l}2,6,8,9,12,18,19,24,27,28, \\
30,31,33,34,35,36,38,42,44, \\
50,55,58,59,60,61,62,63,66, \\
67,72,73,74,75,77,82,85,87, \\
88,89,90,93,94,96,97,103, \\
105,106,115,125,131,132, \\
138,139,140,142,145,148, \\
\begin{array}{l}149,152,159,174,175,177, \\
178,180,181,182,183,187, \\
190,196,197 .\end{array}\end{array}$ \\
\hline Cluster 3 & $\begin{array}{l}1,3,4,5,7,10,11,13,14,15, \\
16,20,21,22,23,25,26,29,32, \\
37,39,40,41,43,46,48,49,51, \\
52,53,56,57,65,68,69,70,71, \\
78,79,80,82,83,84,86,92,95, \\
98,99,100,101,102,104,107, \\
108,109,111,112,113,114,\end{array}$ \\
\hline
\end{tabular}


DOI : 10.29408/jit.v4i1.2986 Link : https://dx.doi.org/10.29408/jit.v4i1.2986

\begin{tabular}{|l|l|ll|}
\hline & $116,117,118,119,120,121$, \\
$123,124,126,127$, & 128,130, \\
$133,134,136,137$, & 140,141, \\
$143,144,146,150$, & 151,153, \\
$154,155,156,157$, & 160,161, \\
$162,163,164,165,167,168$, \\
$170,171,173,176,179,184$, \\
$185,186,188,189,192,193$, \\
$194,195,199,200$.
\end{tabular}

Berdasarkan hasil pengolahan data yang telah Penulis lakukan terdapat 3 golongan kriteria penduduk yang dilihat dari segi penghasilannya yaitu :

a. Penduduk Ekonomi Tinggi

Kelompok penduduk yang memiliki penghasilan mulai dari Rp.3.000.000 sampai Rp.8.000.000 untuk perbulannya.

b. Penduduk Ekonomi Sedang Kelompok penduduk yang memiliki pengasilan perbulannya mulai dari Rp.1.500.00 sampai Rp.2.500.000.

c. Penduduk Ekonomi Rendah

Kelompok penduduk ini memiliki penghasilan yang di dapatkan perbulannya yaitu Rp.1.000.000 kebawah.[15]

\section{Kesimpulan}

Berdasarkan penelitian yang telah dilakukan maka dapat ditarik kesimpulan sebagai berikut :
- Menentukan centroid (titik pusat) pada tahap awal algoritma K-Means sangat berpengaruh pada hasil cluster seperti pada hasil pengujian yang dilakukan dengan menggunakan 200 dataset dengan centroid yang berbeda menghasilkan hasil cluster yang berbeda pula. [16]

- Berdasarkan 3 cluster yang telah dilakukan pengujian menggunakan Rapid Miner bahwa Data Penduduk terbanyak terdapat pada cluster ke-3 yang tergolong pada penduduk ekonomi rendah (Miskin).

\section{Daftar Pustaka}

[1] S. Kasus, T. Usaha, and M. Barabai, "PENERAPAN DATA MINING UNTUK KLASIFIKASI PRODUK MENGGUNAKAN ALGORTIMA K-MEANS," vol. 2, no. 2, pp. 191-198, 2018.

[2] W. P. Hidayanti, "Penerapan Algoritma KNearest Neighbor Untuk Klasifikasi Efektivitas Penjualan Vape ( Rokok El ektrik ) pada 'Lombok Vape On' Infotek J. Inform. dan Teknol., vol. 3, no. 2, 2020.

[3] V. No, W. Purba, and W. Siawin, "IMPLEMENTASI DATA MINING UNTUK PENGELOMPOKKAN DAN PREDIKSI KARYAWAN YANG BERPOTENSI PHK DENGAN ALGORITMA K-MEANS CLUSTERING," vol. 2, no. 2, 2019. 
DOI : 10.29408/jit.v4i1.2986 Link : https://dx.doi.org/10.29408/jit.v4i1.2986

[4] J. I. Komputer, F. Matematika, D. A. N. IImu, and P. Alam, "PENERAPAN METODE CLUSTERING K-MEANS TERHADAP DOSEN BERDASARKAN PUBLIKASI," 2016.

[5] R. W. Sari, A. Wanto, and A. P. Windarto, "IMPLEMENTASI RAPIDMINER DENGAN METODE K-MEANS ( STUDY KASUS: IMUNISASI CAMPAK PADA BALITA BERDASARKAN PROVINSI )," vol. 2, pp. 224-230, 2018.

[6] D. Safira, E. D. Lestari, M. Iffa, and S. Annisa, "BERDASARKAN ANGKATAN KERJA MENGGUNAKAN ALGORITMA KMEANS," vol. 6, no. 1, pp. 26-31, 2020.

[7] I. Method, K. C. Based, S. Value, W. Interface, C. Study, and I. U. M. M. Magelang, "Penerapan Metode K-Means Untuk Clustering Mahasiswa Berdasarkan Nilai Akademik Dengan Weka Interface Studi Kasus Pada Jurusan Teknik Informatika UMM Magelang," vol. 18, no. 1 , pp. 76-82, 2015.

[8] F. Sembiring and S. Saepudin, "IMPLEMENTASI METODE K-MEANS DALAM PENGKLASTERAN DAERAH PUNGUTAN LIAR DI KABUPATEN SUKABUMI ( STUDI KASUS: DINAS KEPENDUDUKAN DAN PENCATATAN SIPIL )," vol. 14, no. 1, pp. 40-47, 2020.
[9] T. Noviana and Y. Novianto, "PENERAPAN DATA MINING MENENTUKAN KELOMPOK PRIORITAS PENERIMA BANTUAN BERAS RASTRA DENGAN CLUSTERING K-MEANS," pp. 159-174.

[10] A. M. Nur and B. Harianto, "Komparasi Algoritma SVM Dan SVM Berbasis PSO Dalam Menganalisis Kinerja Guru SMAN 3 Selong," Infotek J. Inform. dan Teknol., vol. 2, no. 2, pp. 86-94, 2019.

[11] I. Nasution, A. P. Windarto, and M. Fauzan, "Penerapan Algoritma K-Means Dalam Pengelompokan Data Penduduk Miskin Menurut Provinsi," vol. 2, no. 2, pp. 76-83, 2020.

[12] L. Listiani, Y. H. Agustin, and M. Z. Ramdhani, "Implementasi algoritma kmeans cluster untuk rekomendasi pekerjaan berdasarkan pengelompokkan data penduduk," pp. 761-769, 2017.

[13] F. S. Napitupulu, I. S. Damanik, I. S. Saragih, and A. Wanto, "Algoritma KMeans untuk Pengelompokkan Dokumen Akta Kelahiran pada Tiap Kecamatan di Kabupaten Simalungun," vol. 2, no. 1, pp. 55-63, 2020.

[14] S. T. Informatika et al., "e-ISSN 2614-8773 92," vol. 3, no. 2, pp. 92-103, 2020.

[15] N. Rofiqo et al., "PENERAPAN CLUSTERING PADA PENDUDUK YANG MEMPUNYAI KELUHAN KESEHATAN 
DOI : 10.29408/jit.v4i1.2986 Link : https://dx.doi.org/10.29408/jit.v4i1.2986

DENGAN DATAMINING K-MEANS," vol. 2, pp. 216-223, 2018.

[16] Y. P. Sari, A. Primajaya, A. Susilo, and Y. Irawan, "Implementasi Algoritma K-Means untuk Clustering Penyebaran Tuberkulosis di Kabupaten Karawang," pp. 229-239, 2020. 